\title{
LANDSCAPE, COLORED PASSION IN THE CREATION OF ARCHITECT EUGEN BOGNIBOV
}

\author{
Angela Munteanu*, ORCID ID: 0000-0003-4671-022X \\ Technical University of Moldova, Ștefan cel Mare și Sfânt Bd., Chișinău, Republic of Moldova \\ *Corresponding author: Angela Munteanu, angela.munteanu@arh.utm.md
}

Received: 09. 14. 2021

Accepted: 10. 22. 2021

\begin{abstract}
The landscape genre is painting and contemplation through the creation of the architect and professor, doctor of architecture, associate professor Eugen Bognibov, from the Department of Architecture, Faculty of Urbanism and Architecture, Technical University of Moldova. The landscape was certainly one of the favorite types of painting of professional artists, but also for lovers of beauty. The predilection of the architect and painter Eugen Bognibov for the landscape genre can be explained by the fact that the Moldovan lands offer an enormous variety of views and possibilities to practice the landscape: reliefs, forested hills, hills, steppes, roads winding through vineyards, and orchards, cities and villages, water pools, architectural monuments of stone and wood, a true cultural heritage of the country. And the author remarks that the painting dedicated to the architect and professor Eugen Bognibov represents the state of lyricism and harmony, is the link between man and nature, which is distinguished by the colorful freshness of urban, rural, forest landscapes, etc. Various painted views of the historical area of his hometown, Chisinau, images of the morning city bathed in the rays of the generous sun or landscapes near the village of Butuceni, etc. Therefore, the motivation for painting and landscape became for the architect Eugen Bognibov, a free manifestation of his creation through paintings with saturated colors, works presented in various exhibitions.
\end{abstract}

Keywords: artist, landscape, nature, painting, architecture, color.

Rezumat. Genul peisajer este forma de pictură și contemplare prin creație a arhitectului și profesorului, doctor în arhitectură, conferențiar universitar Eugen Bognibov, din cadrul Departamentului Arhitectura, Facultatea Urbanism și Arhitectură, Universitatea Tehnică a Moldovei. Peisajul a fost, cu certitudine, unul dintre genurile de pictură preferate al plasticienilor profesioniști, dar și pentru iubitorii de frumos. Predilecţia arhitectului și pictorului Eugen Bognibov, pentru genul peisajer poate fi explicată, prin faptul că meleagurile moldoveneşti oferă o varietate enormă de privelişti şi posibilităţi de a profesa peisajul: reliefuri, dealuri împădurite, coline, stepe, drumuri ce şerpuiesc printre vii şi livezi, oraşe şi sate, bazine acvatice, monumente de arhitectură din piatră şi lemn, un veritabil patrimoniu cultural al ţării. lar autoarea remarcă că, pictura dedicată a arhitectului și profesorului Eugen Bognibov, reprezintă starea de lirism şi armonie, este liantul dintre om şi natură, care se distinge prin prospețimea coloristică peisajelor citadine, rurale, forestiere ș.a. Diverse vederi 
zugrăvite din zona istorică a orașului natal, Chișinău, imagini a orașului matinal scăldat în razele soarelui generos sau peisaje din preajma satului Butuceni etc. Prin urmare, motivația pentru pictură și peisaj a devenit pentru arhitectul Eugen Bognibov, o manifestare liberă a creației sale prin tablourile cu culori saturate, lucrări prezentate în diverse expoziții.

Cuvinte-cheie: artist, peisaj, natură, pictură, arhitectură, culoare.

\section{Introduction}

We notice that the consolation through painting for some artists is focused on the aesthetic side of the landscape, for them, artists, nature is an "attractive material for contemplation", a reason for joy, "a force that stimulates life"[1, p. 163; 3].

Nature for the creator Eugen Bognibov, is an opportunity for aesthetic delight and becomes a reason for spiritual silence, for thinking about existential and dynamic problems, for inner feelings. Gradually, the artist's dialogue with nature leads to new interpretations of man's relationship with nature, and the image of the painting gets a metaphorical imprint, with a philosophical substratum, of the link between the two. The artist emphasizes the dissension between time and eternity; he invites the viewer to meditate on the message of nature in the landscape exposed to the viewer. The high sonority of the chromatic structure gives the painting a bright atmosphere and stresses the emotional state, the good mood of the inhabitants known and loved by the artist. The author's predilection for certain means of expression and plastic motives reveals the "individuality" of the landscape genre, the accentuated temperament of the architect Eugen Bognibov and the vision of the world.

The genre of landscape, according to the art historian and critic Kenneth Clark (19031983) awakens a special and terrifying feeling, of anxiety, caused by the movements of the wind, the harmony of the picture that seems to connect heaven and earth. The individual perception of the painter has become the most important way of manifestation for the beauty of nature, namely through the genre of landscape, to which are added nostalgic memories [2]. Thus philologists Pietro Fanfani and Giuseppe Rigutini in the explanatory dictionary Vocabolario Italiano della lingua parlata, (1875) define the landscape as a "complete view or part of it, where it is chosen to be the subject of painting. By interpreting the space where the beginning and the infinite merge, the landscape can be interpreted as an outer space - of a locality or a view, seen panoramic, or as an inner space - perceived on a smaller dimensional scale, representing only a fragment of the vastness of the landscape. Within a higher level of plastic processes, a purely intellectual, emotional, and affective product is created, meant to emphasize, here, the role played by a representation of the image in our vision of the world and of the value we attribute to the landscape. [4 - 6].

In the subject's continuation we mention that, according to the assertion of R. Assunto, french painter and pedagogue (Bordeaux 1885-1962, Paris), author of the work "Treatises on landscape and figure", states that the landscape is a representation of an extremely open space and the beauty of nature that many "pass with their eyes wide open, without noticing it...", the painter feels it organically [1 p. 6].

Nature is the source of inspiration for painters

Nictor Hugo/

\section{Idealization of nature in the landscape through color and imagination}

The problem of the idealization of the surrounding world gains new aesthetic forms through the way of compositional structuring, based on the rhythmic dynamism of the daily 
life of this end of the century. Tânărul student, Eugen Bognibov, la UTM, FUA, catedra de Arhitectură, o fire ambițioasă în proiectare de arhitectură dar și pictură peisageră (fig. 1). The young student, Eugen Bognibov, at UTM, FUA, Department of Architecture, an ambitious person in architecture but also landscape painting "Figure 1" [7 - 11].

For the works of Professor Eugen Bognibov, architect and plastic artist, landscape art became the business card, being presented in exhibitions, constituting the vast majority of his works. The painter and architect Eugen Bognibov, with extensive knowledge in architecture and the art of painting, through his refinement and talent as a plastic artist at a much higher level, the master leaned on the sporadic landscape, hoping to find the harmony of nature and peace of mind. The paintings made over the years differ substantially, their artistic value is determined by the mode of expression, the subject presented, the connotation, and the impact of the times. All have become an inexhaustible source for the artist who opted for landscape in his creation [6 - 9].

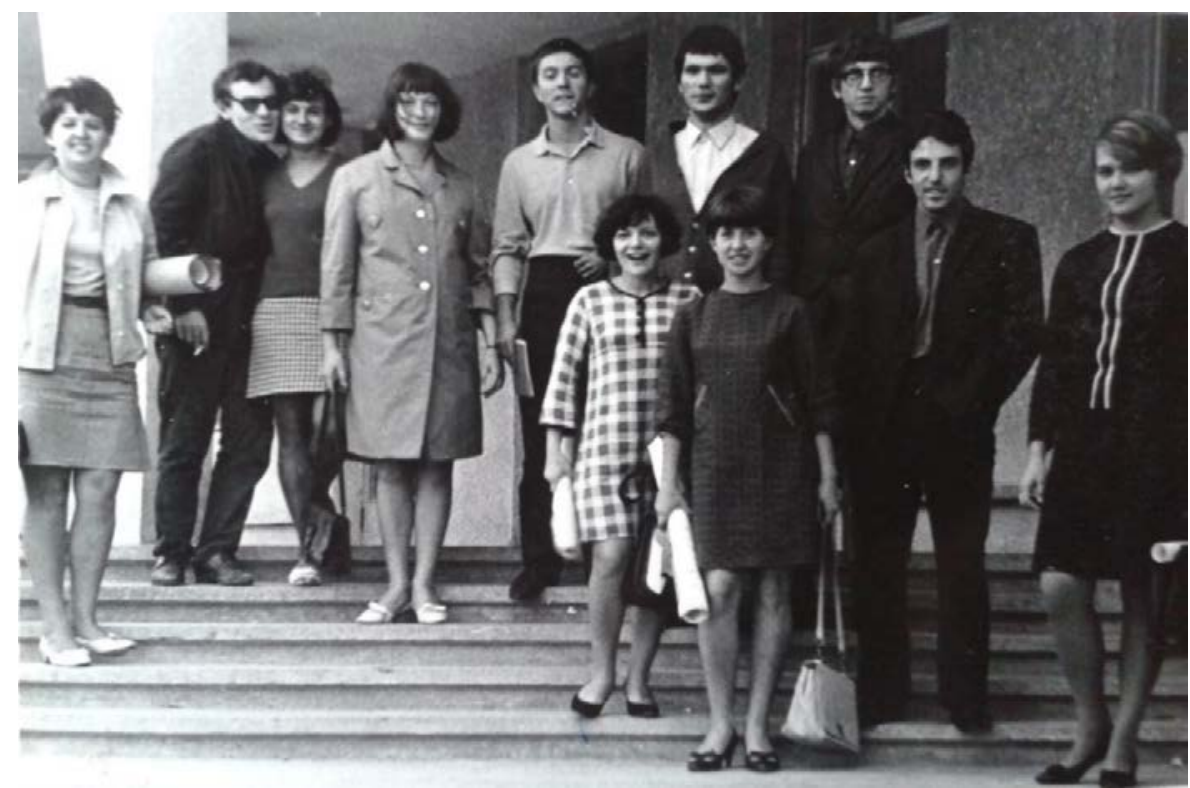

Figure 1. Student years Eugen Bognibov, future architect (right).
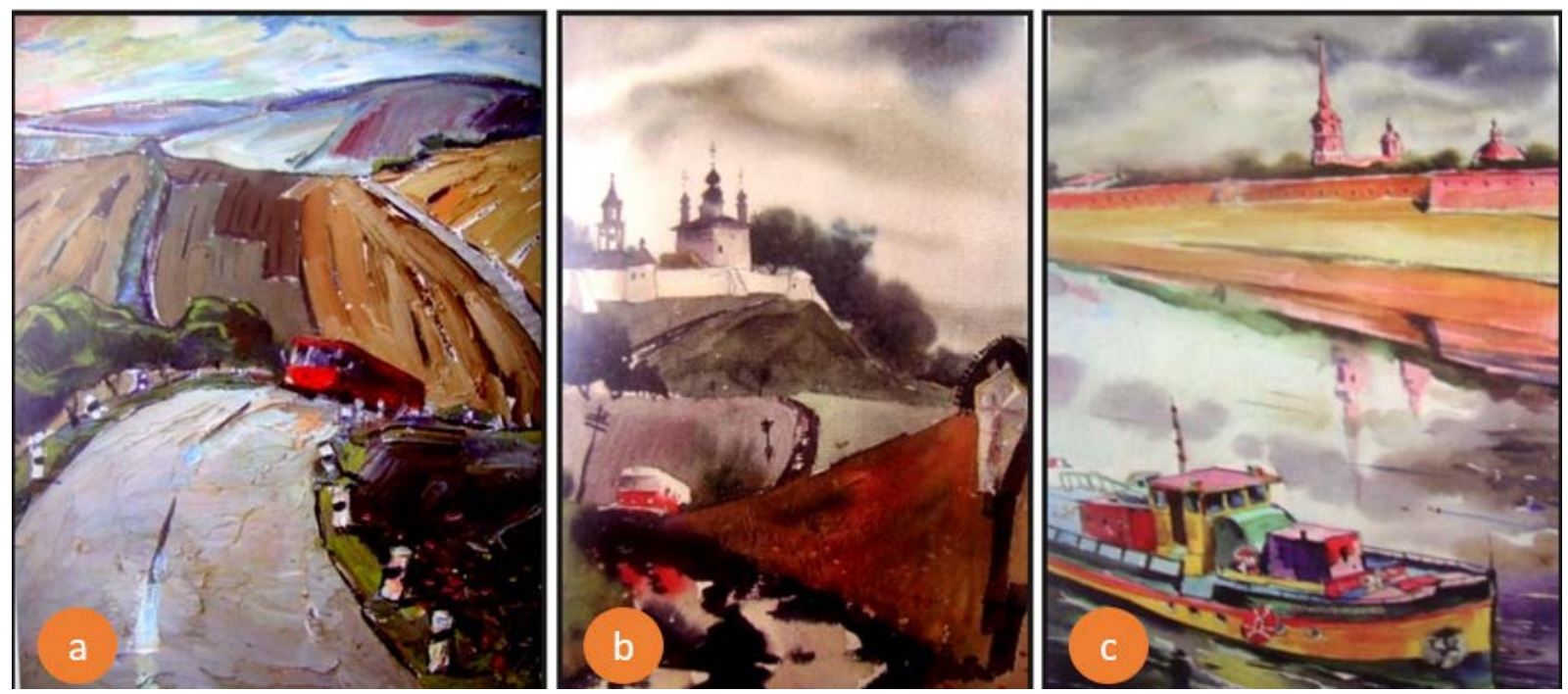

Figure 2. Eugen Bognibov. a) Road from Butor, 2001, 48x70 cm, oil / canvas;

b) The roads of Russia. Suzdal, 1985, $24 \times 37 \mathrm{~cm}$, a/ paper;

c) Sankt- Petersburg, 2006, 30×50 cm, a/paper. 
Thus, the principles and ways of approaching the landscape, of the painter Eugen Bognibov, evolved, diversifying the preferences towards certain landscapes: riverside, mountain, rural, architectural with panoramic views: Road from Butor (Drum de la Butor) (2001), The roads of Russia. Suzdal (Drumurile Rusiei) (1985), St. Petersburg (2006) "Figure 2 a, b, c", lyrical landscapes with a small church in the middle of the landscape composition with architectural elements, with winding roads in the background, made of canvas and cardboard, in the technique of oil and watercolor colors, amazing us by the professionalism they.

Most landscape painters give the predilection for epic-romantic images treated according to the principle of "bird flight" (obtained by raising the horizon above the middle of the painting). This panoramic view gives epic grandeur to the simplest motifs in nature with roads, locality, wide plains, hills, etc., and contributes to the evocation of the beauty of nature and to the propagation of the idea of the greatness of the native country.

The artist chooses observation points from where you can admire the beauty of nature in all its complexity and diversity. The painter Eugen Bognibov, operating with contrast effects, uses multi-plane rhythmic constructions with wide, perspective openings [12].

The landscape continued to be a possibility to express the true reality in the paintings of the master Eugen Bognibov, of compositional and chromatic solution of the works: On the lakes of Lithuania (1988), Winter in Suzdal (1987) (figure 3, a, b), with an exact, architectural drawing, a dynamics of forms and expression of feelings, with a special treatise, affection, and professionalism. The high sonority of the chromatic structure gives the landscape paintings, represented from different places of Moldova, Lithuania, and Russia, a bright atmosphere and accentuates the emotional state, which awakens associative ideas of joy and well-being [8 - 10].
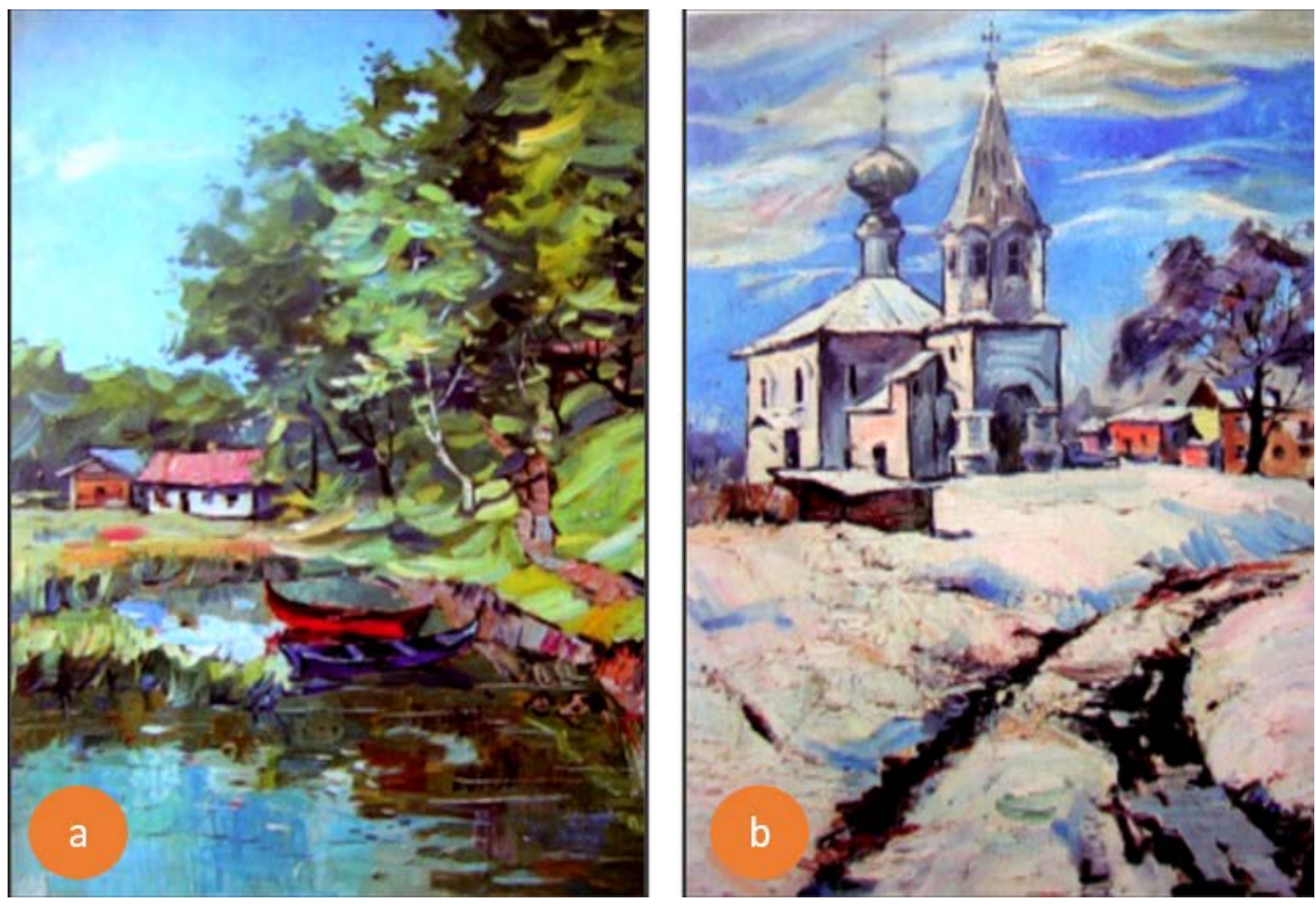

Figure 2. Eugen Bognibov. a) On the lakes of Lithuania, 1988, $48 \times 70 \mathrm{~cm}$, oil/canvas; b) Winter in Suzdal, $1987,48 \times 70$ cm, oil/canvas. 


\section{Professional creation: nature - the space of contemplation with architecture}

Following step by step the evolution and constitution of the landscape in the creation of the architect, Professor Eugen Bognibov, in different periods of time, we meet the series of summer and autumn landscapes: Suffocating summer. Close to silence, Near the Dniester river, Autumn landscape, Forest path, etc. "Figure 3-a, b, c"; "Figure 4-a, b, c" with unpretentious motifs, plains and rhythmic alternation of trees, hills with water surfaces, an invaluable source of colorful emotions in the summer or autumn season. In his tendency to reflect certain aspects of nature, the painter Eugen Bognibov, chooses different dominant typical of the landscape of our country - hills, plains, vineyards, roads between hills, meandering rivers -, which he treats mostly in a lyrical-poetic vision. This poetic formula is reflected in idyllic or nostalgic images of the "spatial" landscape, which awakens in the viewer's soul the feeling of greatness of nature in different colorful seasons. [13 - 14].
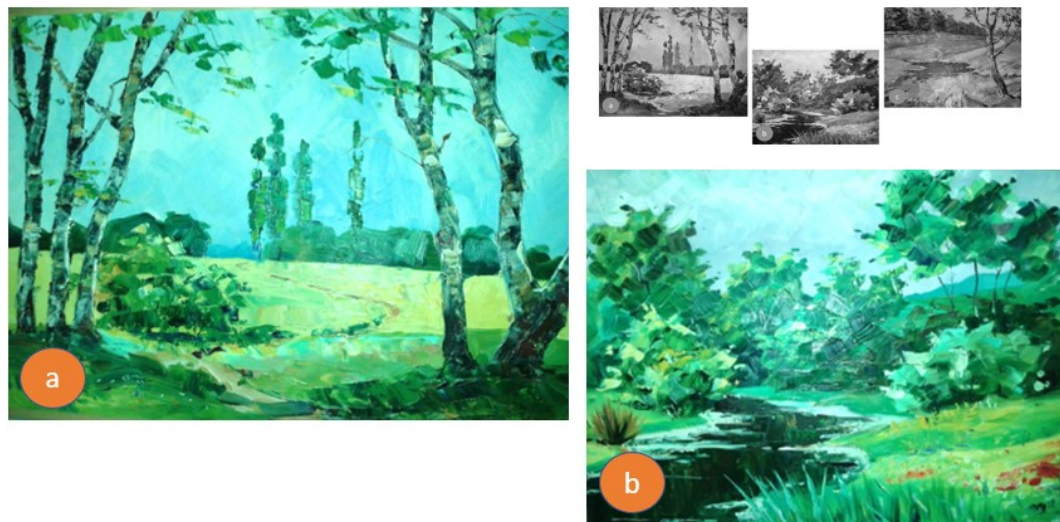

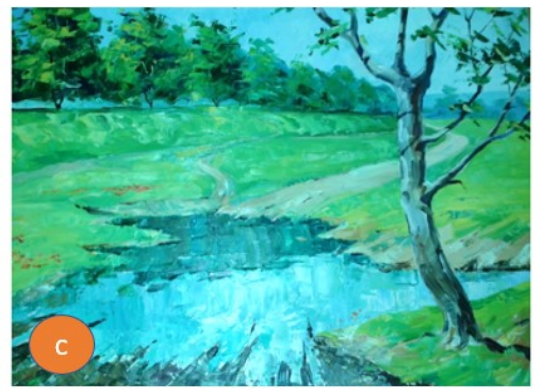

Figure 3. Eugen Bognibov. a) Suffocating summer; b) The approach of silence; c) Water landscape.
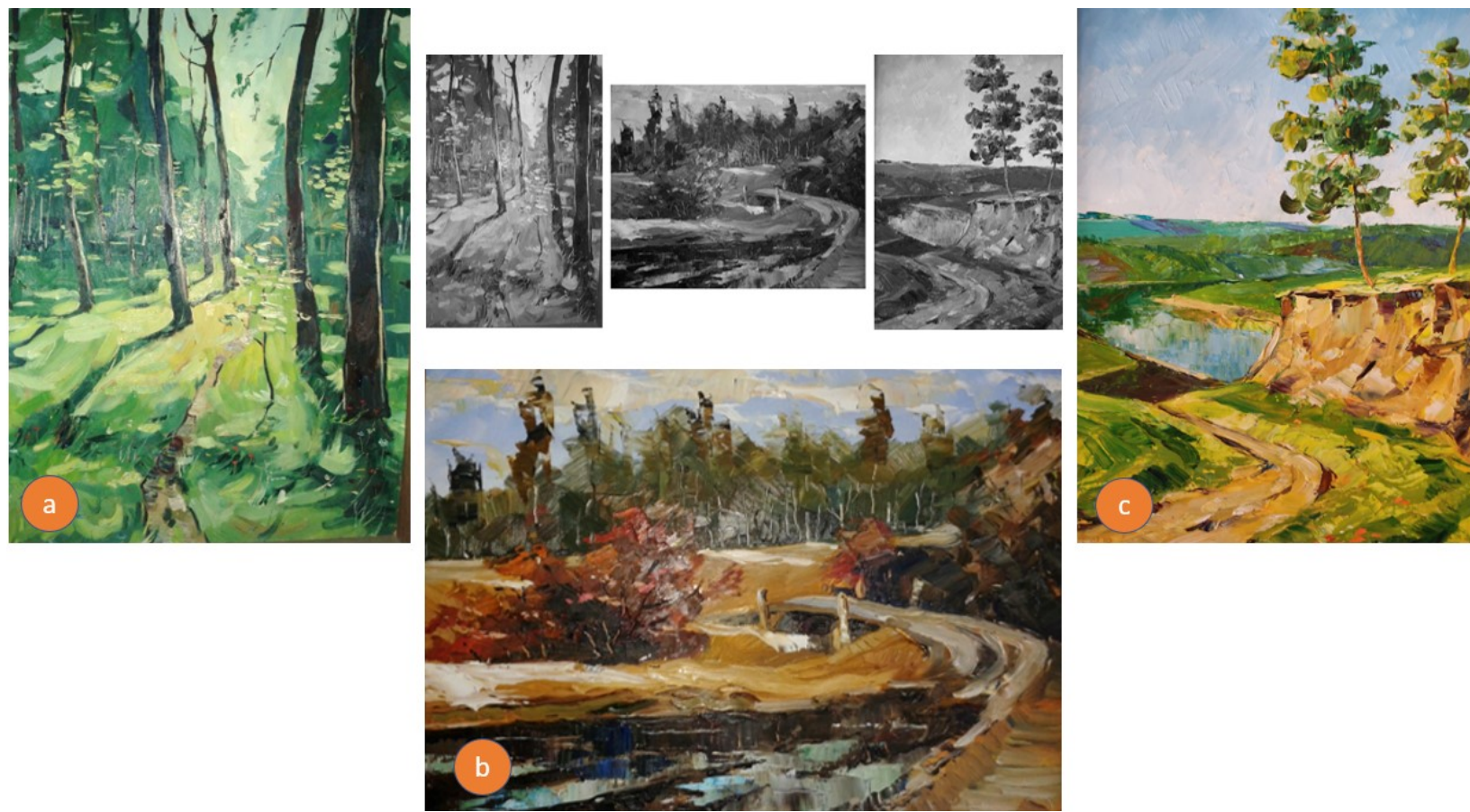

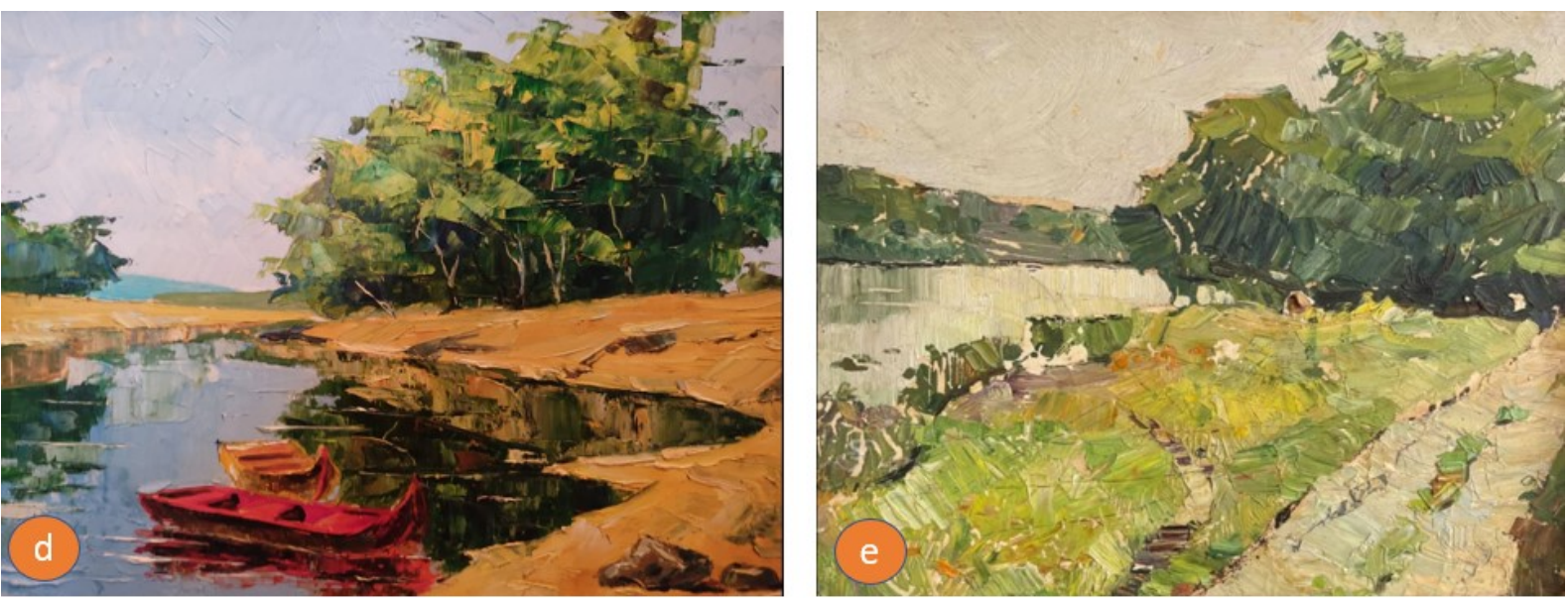

Figure 4. Eugen Bognibov. a) Forest path near Dniester river; b) Autumn landscape; c) On the bank of the Dniester oil / canvas; d, e) Landscapes with water, oil on canvas.

Nature is made up of contrasts: every light has its shadow Nictor Hugo/

Panoramic works from different picturesque places of Moldova, we observe landscape views: Winter landscapes, "Figure 5, a, b" panoramic compositions, where the principles of treating the depth of space are modeled through light and shade. Forest landscapes that convey the lyrical-epic state of Moldovan nature and its temperate character with cold colors. The landscape-space identity in the chromatic treatment of the genre in the works of professor Eugen Bognibov emanates the state of lyricism and harmony between man and nature, which is distinguished by the freshness of color $[10,14]$.
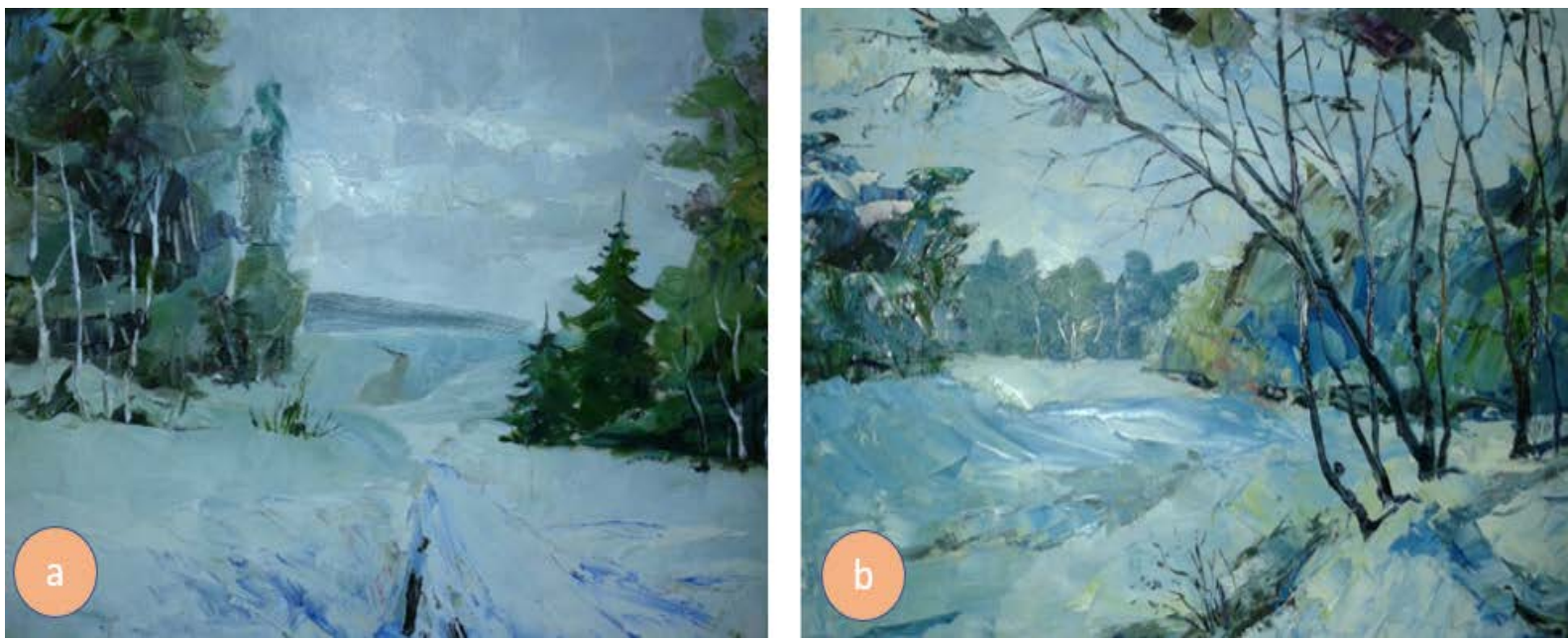

Figure 5. Eugen Bognibov. a, b) Winter landscapes.

The series of landscapes dedicated to the hometown of Chisinau: Morning Chisinau, Urban Landscape, "Figure 6, a, b, c" represent images with historical monuments of historical architecture, with a rich decorative and stylistic ornamentation. Neighborhoods with one or two level houses in the historic heart of the capital, are "awakened" by the rays of the morning sun, with quiet alleys are flooded with greenery. The streets of the alleys represent the systematization plan of the neighborhoods with rhythmic forms, and in the center of the composition, there is a dominant vertical and the sky studded with floating clouds in spots of faded and warm colors, is the historical picture of national architecture, painted by painter and architect Eugen Bognibov [8 - 10; 13 - 14]. 

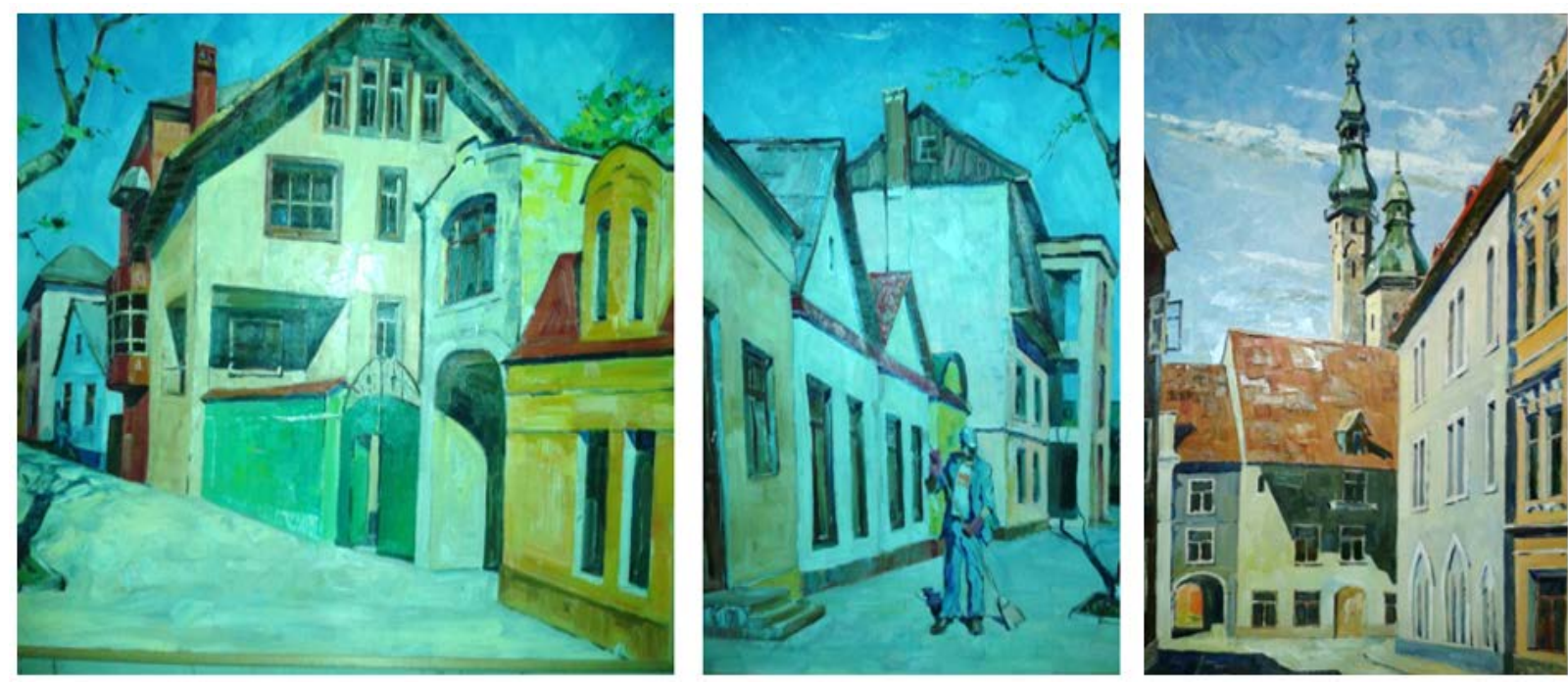

Figure 6. Eugen Bognibov. a, b, c) Morning Chisinau, Cityscape, oil / canvas.

\section{Conclusions}

In conclusion, we mention that the paintings dedicated to the genre of landscape loved and painted on canvas by Eugen Bognibov, are undoubted, above all, the space and subject of experience, but also the object of aesthetic judgment. The deliberate interpretation of the components - landscape, space, architecture, as terms of harmonious relations, lead to the alignment of a philosophical identity between subject and predicate. The landscape in the author's paintings, with its role of generating the image of plastic space, becomes a source of inspiration for the architect, painter Eugen Bognibov, a source of aesthetic delight, a refuge from everyday life, a way of expressing the viewer's sincere message of their feelings and turmoil. The comparative analysis of landscape works, painted by the author, highlights the major role of the landscape in his artistic creation. This genre, for the master Eugen Bognibov, becomes a passion, which emanates the state of lyricism and harmony between man and nature.

\section{References}

1. Assunto R. Landscape and aesthetics (translated into Romanian by Olga Mircelescu). Bucharest: Meridiane, vol. I, 1986, 472 p., [In French].

2. Kenneth C. Landscape in Art (1947), translated into Romanian by Eugen Filotti, entitled Landscape Art, 1969), 157 p., [In French].

3. Lhote A. Treatises on landscape and figure (Romanian translation by D. Dancu). Bucharest: Meridiane, 1969, [In French].

4. Rigutini G. \& Fanfani P. Italian vocabulary of the spoken language-criteria, practices, evolution. (1875), University of Chieti-Pescara, $172 \mathrm{p}$.

5. Zingarelli N. Dictionary of the Italian language. Florence, Zanichelli, 1941, p. 48

6. Prut C. Dictionary of modern and contemporary art. Bucharest, 2002, p. 69 - 70, [In Romanian].

7. Bognibov E. A. Architecture of the Moldavian SSR. În: Codru, no. 11, 1975, [In Russian].

8. Munteanu A. The landscape is the only source of eternal inspiration. The kind of landscape explored by UTM professors and the Architecture department. In: Collection of articles 8th edition, volume I, 2014, Chisinau: TUM, FUA, Department of Theory and Practice of Architecture and Urbanism, pp. 96-111, ISBN 978-997571-011-44 0.5 sheets of printing, "Tehnica - UTM" Publishing House, [In Romanian].

9. Munteanu A. Architects, plastic artists, professors at the FUA Architecture Department, TUM, 2015-2016. In the Collection "Identities of Chisinau", 3rd edition, pp. 265-273, ISBN 978-9975-61-871- 74, 1.5 printing sheets, Arc-Chisinau Publishing House -2016, [In Romanian]. 
10. Munteanu A. Nature landscape is a source of inspiration for painters and architects. In: Collection of articles, volume III, November 15 - 23, 2013, Chisinau: UTM, FUA, pp. 421-424, ISBN 978-9975-45-310-3, volume: 0.35 sheets of paper, Publishing House "Technique - UTM", [In Romanian].

11. Munteanu G. Files from the didactic activity of the plastic artist Gheorghe Munteanu (disciple Eugen Bognibov). Kishinev, 2009, [In Romanian].

12. Pleşu A. Picturesque and melancholy. An analysis of the feeling of nature in European culture. Bucharest: Univers, 1980, 180 p., [In Romanian].

\section{Web references:}

13. Nesterov T. Post-war architecture of Soviet Moldova. In the magazine Arta, IBN: [online]. 08.02. 2017 [access 02.07.2021]. Available:

https://ibn.idsi.md/sites/default/files/imag_file/96_103_Arhitectura\%20din\%20perioada\%20postbelica\%20 a\%20Moldovei\%20sovietice.pdf

14. The link of the works on Eugen Bognibov's facebook page [online]. 01.01.2018 [access 29.06.2021]. Available: https://www.facebook.com/profile.php?id=100006884118594 